\title{
ВПЛИВ НАНОДЕФЕКТІВ ШАРІВ НА ПРОПУСКАННЯ СВІТЛА ОПТИЧНИМИ ЕЛЕМЕНТАМИ З БАГАТОШАРОВИМИ ІНТЕРФЕРЕНЦІЙНИМИ ПОКРИТТЯМИ
}

\author{
I.В. ФЕКЕШГАЗІ, ${ }^{1}$ Т.С. СІДЕНКО,${ }^{1}$ О.В. МІЦА,${ }^{2}$ П. БАРНА, ${ }^{3}$ \\ O.E. KIKIHEWI
}

\author{
${ }^{1}$ Інститут фізики напівпровідників ім. В.Є. Лашкарьова НАН України \\ (Просn. Науки, 41, Kиїв 03028; e-mail: fek_i@ yahoo. com) \\ ${ }^{2}$ Ужгородський державний університет \\ (Вул. Волошина, 54, Ужгород 88000; e-mail: alex_mitsa@mail.ru) \\ 3 Дослідний інститут технічної фізики та матеріалознавства, \\ Академія наук Угорщини \\ (Konkoly-Thege ut. 29-33, Budapest, Hungary; e-mail: barnap@mfa.kfki.hu) \\ ${ }^{4}$ Інститут ядерних досліджень, Академія Наук Угорщини \\ (Middelheimlaan, 1, Deberzen 2020, Hungary)
}

\begin{abstract}
Досліджено залежність пропускання світла оптичними елементами з багатошаровими інтерференційними покриттями. Встановлено, що максимуми пропускання оптичних елементів з реальними покриттями, які мають дефекти, знижуються тим сильніше, чим вищі показники заломлення речовини дефектів, а форма кривих пропускання суттєво залежить від розмірів дефектів уздовж напрямку поширення світла та їх положення в об'ємі дефектного шару. Дані результати необхідні для відпрацьовування технології виготовлення оптичних елементів 3 багатошаровими інтерференційними покриттями як для лазерної техніки, так і для виробництва оптичних лінз.
\end{abstract}

\section{1. Вступ}

Як відомо, високоякісні та оптично однорідні плівки широко використовуються для розробки функціональних елементів у приладах оптоелектроніки та лазерної техніки (фільтрах, просвітлюючих покриттях, потоко- та спектроподілювачах, поляризаторах тощо) [1]. Нині досить добре досліджені електрофізичні та оптичні властивості ізольованих плівок, їх зв'язок з технологіями отримання, вплив наявності нанодефектів в об'ємі плівок на їх властивості, а також можливості практичного застосування. Резуль- тати таких досліджень стали предметом обговорення на багатьох конференціях $[2,3]$. Сучасні технології осадження тонких плівок вимагають відсутності дефектів в їх об'ємі, оскільки наявність проколів, тріщин та надривів суттєво погіршує параметри плівок, що може привести навіть до їх деструкції. Однак цього не завжди вдається уникнути, тому в багатьох роботах широко досліджується вплив нанодефектів на властивості тонких плівок. У даній роботі проаналізовано теоретичні та експериментальні результати дослідження впливу нанорозмірних дефектів на оптичне пропускання чотиришарової інтерференційної системи просвітлюючого типу, яка широко використовується на практиці (особливо для виготовлення оптичних лінз окулярів).

\section{2. Експериментальні зразки}

У сучасному виробництві оптичних лінз широко використовуються інтерференційні покриття, що створюються періодичним повторенням шарів з оксиду цирконію $\left(\mathrm{ZrO}_{2}\right.$, має високий показник заломлення $\left.n_{A}=2,11\right)$ та фториду магнію $\left(\mathrm{MgF}_{2}\right.$, має низький показник заломлення $\left.n_{B}=1,38\right)$, які наносяться на 


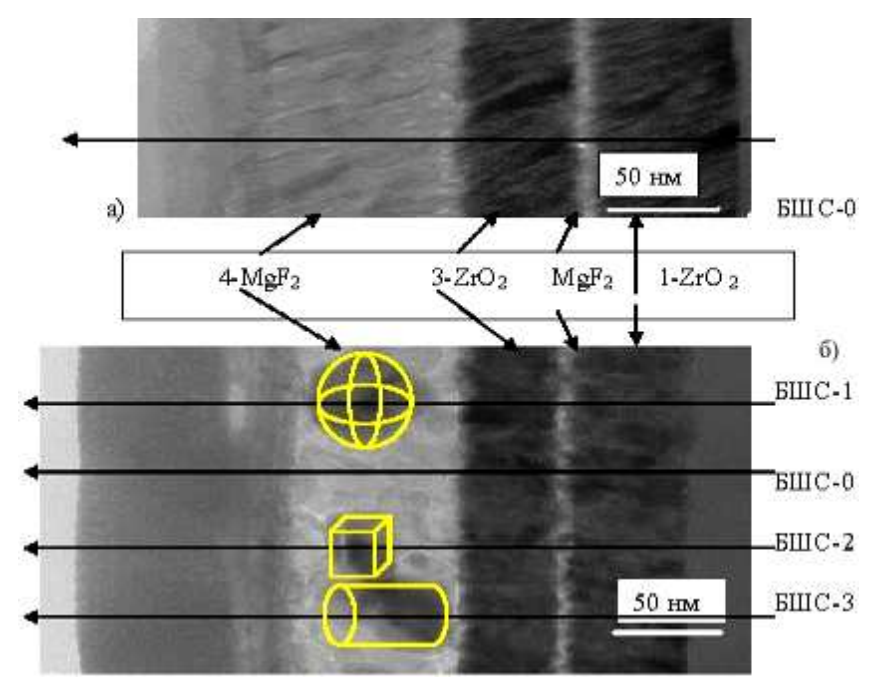

Рис. 1. Поперечний переріз БШС структур без дефектів ( $a$, система БШС-0) та з дефектами (6, системи БШС-1, БШС-2, БШC-3)

прозору підкладку (показник заломлення $n=1,9$ ). Встановлено, що для підвищення пропускання світла оптичними лінзами достатньо нанести лише чотири шари таких плівок різної геометричної товщини (див. рис. $1, a$, багатошарова структура БШС-0). Однак на практиці трапляється, що в деякому шарі можуть виникнути дефекти (найчастіше у зовнішньому досить товстому шарі $\mathrm{MgF}_{2}$, який межуе з повітрям). У цьому випадку чотиришарова структура перетворюється на шестишарову (рис. 1,б, БШС-1, БШС-2, БШС- 3), оскільки сам дефект утворює дві межі. За просторовою конфігурацією всі дефекти можна подати як сфери (БШС-1), паралелепіпеди (БШС-2) та циліндри (БШС-3). На рис. 1,б зображено поперечний переріз БШС площиною, що включає напрямок поширення світла. Геометричні та оптичні товщини шарів усіх отриманих БШС наведено в табл. 1.

\section{3. Аналіз результатів розрахунків}

Багатошарові структури, зображені на рис. 1,a,б, можна схематично подати як прозорі підкладки $\mathrm{S} 3$ показником заломлення $n_{S}$, на які послідовно один за одним осаджено шари А з високим показником заломлення $n_{A}$ та шари В з низьким показником заломлення $n_{B}$ (див. рис. 2).
Оптичні товщини шарів визначаються множниками $x_{i} \mathrm{~A}$ та $y_{i} \mathrm{~B}$ для відповідних чвертьхвильових шарів $\mathrm{A}$ i $\mathrm{B}$, для яких справедливе співвідношення $n_{A} d_{\mathrm{A}}=$ $n_{B} d_{B}=\lambda_{0} / 4$, де $d_{\mathrm{A}}$ - геометрична товщина шару $A$, $\lambda_{0}-$ робоча довжина хвилі (наприклад, колір скла лінз окулярів). Геометричний вигляд дефектних шарів у БШС схематично показано на рис. 3.

Відповідні структури дефектного шару будуть такими, як на рис. 2,б, якщо матеріал дефекту збігається з речовиною А, або такими, як на рис. 2, в, якщо дефект утворюється повітрям.

Для оцінки впливу зміни параметрів структури інтерференційних систем на результуюче пропускання використано матричний метод розрахунку, в основі якого лежить вибір характеристичної матриці. Якщо геометрична товщина шару дорівнює $d$, а показник заломлення - $n$, то характеристична матриця однорідної діелектричної плівки має вигляд

$M(n, d, \lambda)=\left\|\begin{array}{cc}\cos \delta(n, d, \lambda) & -(i / p) \sin \delta(n, d, \lambda) \\ i p \sin \delta(n, d, \lambda) & \cos \delta(n, d, \lambda)\end{array}\right\|$

де $\delta(n, d, \lambda)=2 \pi n d \cos \theta / \lambda-$ фазова товщина шару, $p=\sqrt{\varepsilon / \mu} \cos \delta, \theta-$ кут між напрямком поширення випромінювання та нормаллю до поверхні розділу шарів [4-6]. Для випадку, коли напрямок поширення випромінювання збігається з нормаллю до поверхні поділу $\theta=0$ відповідно, маємо $p=n$.

Якщо відома характеристична матриця одного шару, можна визначити характеристичну матрицю $k$ шарової структури як добуток матриць для кожного із шарів:

$$
\begin{aligned}
& M(\bar{n}, \bar{d}, \lambda)=M_{k}\left(n_{k}, d_{k}, \lambda\right) M_{k-1}\left(n_{k-1}, d_{k-1}, \lambda\right) \times \\
& \times \cdots \times M_{2}\left(n_{2}, d_{2}, \lambda\right) M_{1}\left(n_{1}, d_{1}, \lambda\right),
\end{aligned}
$$

де $M_{j}$ - характеристична матриця $j$-го шару; $\bar{n}=$ $\left(n_{1}, n_{2}, \ldots, n_{k-1}, n_{k}\right)$ - вектор величин показників заломлення шарів; $\bar{d}=\left(d_{1}, d_{2}, \ldots, d_{k-1}, d_{k}\right)$ - вектор геометричних товщин шарів.

Враховуючи (2), можна знайти величину пропускання БШС, що складається з чотирьох шарів при фіксованих значеннях $\bar{n}, \bar{d} \mathrm{i} \lambda$ :

$T(\bar{n}, \bar{d}, \lambda)=1-\left[\left|\frac{n_{0}\left(M_{11}(\bar{n}, \bar{d}, \lambda)+n_{S} M_{12}(\bar{n}, \bar{d}, \lambda)\right)-\left(n_{S} M_{22}(\bar{n}, \bar{d}, \lambda)+M_{21}(\bar{n}, \bar{d}, \lambda)\right)}{n_{0}\left(M_{11}(\bar{n}, \bar{d}, \lambda)+n_{S} M_{12}(\bar{n}, \bar{d}, \lambda)\right)+\left(n_{S} M_{22}(\bar{n}, \bar{d}, \lambda)+M_{21}(\bar{n}, \bar{d}, \lambda)\right)}\right|\right]^{2}$ 
ВПЛИВ НАНОДЕФЕКТІВ ШАРІВ НА ПРОПУСКАННЯ СВІТЛА

Т а б л и ц я 1. Типи БШС і товщини шарів, нм

\begin{tabular}{|c|c|c|c|c|c|c|c|c|c|c|c|c|c|c|}
\hline \multirow[t]{3}{*}{ Речовина шару } & \multicolumn{14}{|c|}{ Типи БШС і товщини шарів, нм } \\
\hline & \multicolumn{2}{|c|}{ БШС-0 } & \multicolumn{2}{|c|}{ БШС-1-1 } & \multicolumn{2}{|c|}{ БШС-1-2 } & \multicolumn{2}{|c|}{ БШС-2-1 } & \multicolumn{2}{|c|}{ БШС-2-2 } & \multicolumn{2}{|c|}{ БШС-3-1 } & \multicolumn{2}{|c|}{ БШС-3-2 } \\
\hline & геом. & опт. & геом. & опт. & геом. & опт. & геом. & опт. & геом. & опт. & геом. & опт. & геом. & опт. \\
\hline $\mathrm{ZrO}_{2}$ & 60 & 126,6 & 60 & 126,6 & 60 & 126,6 & 60 & 126,6 & 60 & 126,6 & 60 & 126,6 & 60 & 126,6 \\
\hline $\mathrm{MgF}_{2}$ & 10 & 13,8 & 10 & 13,8 & 10 & 13,8 & 10 & 13,8 & 10 & 13,8 & 10 & 13,8 & 10 & 13,8 \\
\hline $\mathrm{ZrO}_{2}$ & 50 & 105,5 & 50 & 105,5 & 50 & 105,5 & 50 & 105,5 & 50 & 105,5 & 50 & 105,5 & 50 & 105,5 \\
\hline $\mathrm{MgF}_{2}$ & 80 & 110,4 & 22 & 30,4 & 22 & 30,4 & 30 & 41,48 & 30 & 41,48 & 10 & 13,8 & 10 & 13,8 \\
\hline $\mathrm{ZrO}_{2}$ & - & - & 40 & 84,4 & & & 25 & 53 & & & 50 & 105,5 & & \\
\hline Повітря & & & & & 40 & 40 & & & 25 & 25 & & & 50 & 50 \\
\hline $\mathrm{MgF}_{2}$ & - & - & 18 & 24,8 & 18 & 24,8 & 25 & 37,4 & 25 & 37,4 & 20 & 27,6 & 20 & 27,6 \\
\hline
\end{tabular}

\begin{tabular}{|c|}
\hline Повітря $n=1$ \\
\hline \\
$y_{2} B$ \\
\hline$x_{2} A$ \\
\hline$y_{1} B$ \\
\hline$x_{1} A$ \\
\hline Підкладка з $n_{S}=1.9$ \\
\hline а)
\end{tabular}

a)

\begin{tabular}{|c|}
\hline Повітря $n=1$ \\
\hline$y_{3} B$ \\
$x_{3} A$ \\
$y_{2} B$ \\
\hline$x_{2} A$ \\
\hline$y_{1} B$ \\
\hline$x_{1} A$ \\
\hline Підкла,дка $3 n_{S}=1.9$ \\
\hline
\end{tabular}

6)

\begin{tabular}{|c|}
\hline Повітря $n=1$ \\
\hline$y_{3} B$ \\
$x_{3} C$ \\
$y_{2} B$ \\
\hline$x_{2} A$ \\
\hline$y_{1} B$ \\
\hline$x_{1} A$ \\
\hline Підкладдка з $n_{S}=1.9$ \\
\hline
\end{tabular}

в)

Рис. 2. Модель БШС без дефектів (a), з дефектами, утвореними $\mathrm{ZrO}_{2}$ (б), та з дефектами, утвореними повітрям (в)

де $n_{0}, n-$ коефіцієнти заломлення зовнішнього оточення та підкладки відповідно, $M_{11}, M_{12}, M_{21}, M_{22}-$ елементи характеристичної матриці $M[5-7]$.

Для чисельних розрахунків спектрів пропускання БШС діючий функціонал задавали у вигляді

$\max _{\bar{n}, \bar{d}} F(\bar{n}, \bar{d})=\left(\frac{1}{L} \sum_{i=1}^{L} T^{2}\left(\bar{n}, \bar{d}, \lambda_{i}\right)\right)^{1 / 2}$,

де $L$ - число точок сітки для спектрального інтервала від $\lambda_{1}$ до $\lambda_{2}$. При однорідному розбитті інтервала 3 кроком $\Delta \lambda$ :

$L=\frac{\lambda_{2}-\lambda_{1}}{\Delta \lambda}+1$

де $\lambda_{1}$ i $\lambda_{2}$ - довжини хвиль на границях досліджуваного діапазону спектра $[6,7]$.

Спектральні залежності пропускання БШС розраховували за формулою (3) 3 використанням параметрів шарів, наведених у табл. 1, і зображено на рис. 4. Було встановлено, що існування дефектів у шарі $\mathrm{MgF}_{2}$ приводить до значного зниження максимумів пропускання та їх зсуву в довгохвильову область спектра. Більш істотне зменшення коефіцієнта пропускання спостерігалося у випадку, коли дефект утворювався речовиною з більшим показником

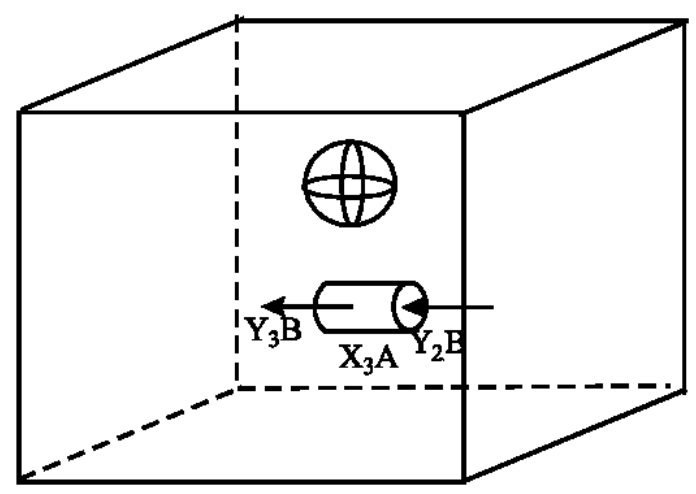

Рис. 3. Геометричний вигляд дефектного шару в БШС

заломлення, наприклад, $\mathrm{ZrO}_{2}$ (криві 3-1 та 3-2 на рис. 4) або мав більший геометричний розмір $[9,10]$.

Як видно з рис. 4, $а$ за наявності дефектів, утворених з $\mathrm{ZrO}_{2}$, характер спектральної залежності змінюється (на ній з'являється мінімум в області 525 нм, а максимум зсувається у довгохвильову область та зменшується його амплітуда приблизно на 10\%). Якщо дефекти шару утворені повітрям (рис. 4,б), то характер спектральної залежності зберігається, а ㄲï максимум також зсувається у короткохвильову область. 
Т а б л ц я 2. Види БШС з геометричним розміром дефекту 20 нм з речовин, що мають різні показники заломлення

\begin{tabular}{|c|c|c|c|c|c|c|c|c|c|c|}
\hline \multirow{3}{*}{$\begin{array}{c}\text { Речовина } \\
\text { шару }\end{array}$} & \multicolumn{10}{|c|}{ Види БШС- $n$ і товщини шарів, нм } \\
\hline & \multicolumn{2}{|c|}{ БСШ-0 } & \multicolumn{2}{|c|}{ БСШ- $n=1$} & \multicolumn{2}{|c|}{ БСШ- $n=2$} & \multicolumn{2}{|c|}{ БСШ- $n=3$} & \multicolumn{2}{|c|}{ БСШ- $n=4$} \\
\hline & геом. & опт. & геом. & опт. & геом. & опт. & геом. & опт. & геом. & опт. \\
\hline $\mathrm{ZrO}_{2}$ & 60 & 126,6 & 60 & 126,6 & 60 & 126,6 & 60 & 126,6 & 60 & 126,6 \\
\hline $\mathrm{MgF}_{2}$ & 10 & 13,8 & 10 & 13,8 & 10 & 13,8 & 10 & 13,8 & 10 & 13,8 \\
\hline $\mathrm{ZrO}_{2}$ & 50 & 105,5 & 50 & 105,5 & 50 & 105,5 & 50 & 105,5 & 50 & 105,5 \\
\hline $\mathrm{MgF}_{2}$ & 80 & 110,4 & 30 & 41,4 & 30 & 41,4 & 30 & 41,4 & 30 & 41,4 \\
\hline дефект & - & - & 20 & 20 & 20 & 40 & 20 & 60 & 20 & 80 \\
\hline $\mathrm{MgF}_{2}$ & - & - & 30 & 41,4 & 30 & 41,4 & 30 & 41,4 & 30 & 41,4 \\
\hline
\end{tabular}

a)

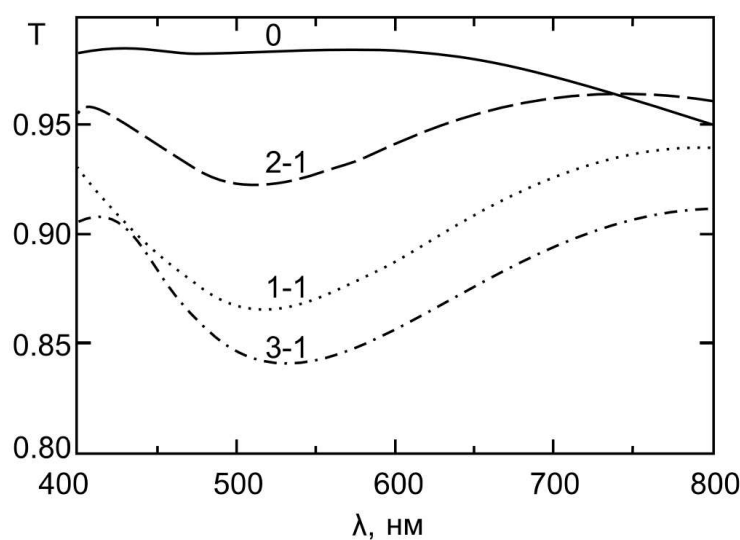

б)

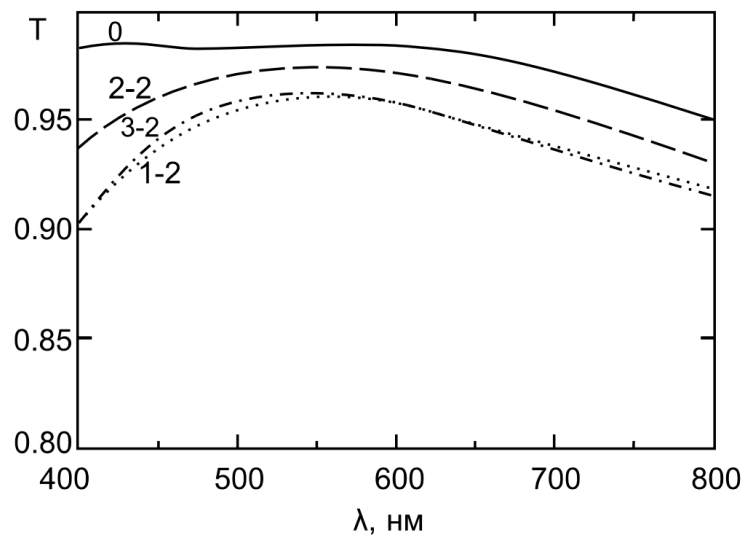

Рис. 4. Спектри пропускання БШС без дефектів (крива 0 ) та з дефектами, утвореними $\mathrm{ZrO}_{2}$ ( $а$, криві 1-1, 2-1, 3-1), і повітрям (6, криві 1-2, 2-2, 3-2)

Також було встановлено, що спектри пропускання БШС-0 без дефектів (рис. 1,a) ідентичні спектрам пропускання у вільній від дефектів області БШС-0 на рис. 1,б, тобто дефекти є електронейтральними i не впливають на оптичні характеристики суміжних областей.

Дані для шарів структури з різними типами дефектів, що мають постійний поздовжній розмір 20 нм, але різну оптичну товщину, яка визначається показником

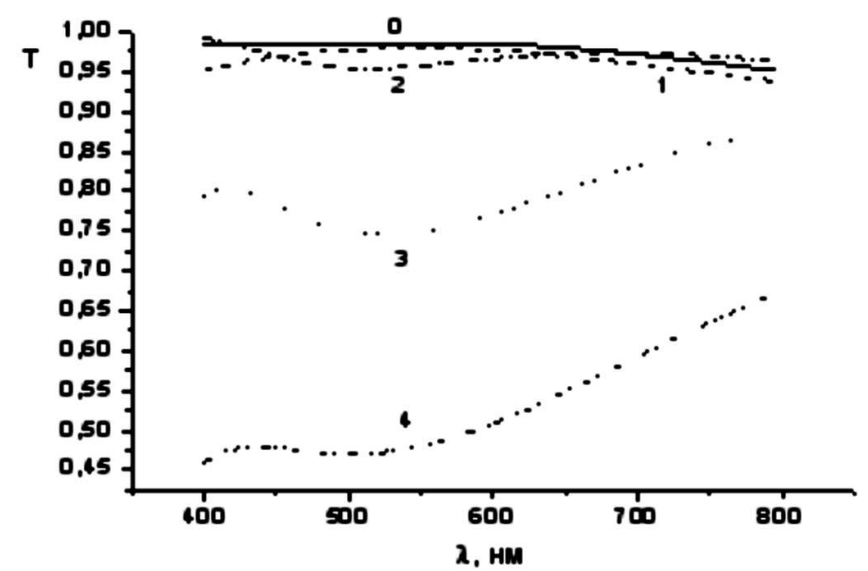

Рис. 5. Спектри пропускання БШС- $n$ без дефектів (крива 0) i з дефектами, що утворені речовинами з показниками заломлення $n=1$ (крива 1), $n=2$ (крива 2), $n=3$ (крива 3), $n=4$ (крива 4)

заломлення речовини дефекту, наведено в табл. 2 Відповідні спектри пропускання показано на рис. 5.

Аналіз зображених на рис. 5 спектрів пропускання показує, що чим більший показник заломлення речовини, з якої утворений дефект, тим сильніший характер змін цих кривих спостерігається (утворення мінімуму на кривих, зменшення абсолютної величини пропускання майже вдвічі при $n=4$, зсув максимуму кривої у довгохвильову область).

Було проведено також більш детальне дослідження пропускання інтерференційної системи залежно від параметрів дефектів - ї геометричних розмірів та розташування відносно меж шару $\mathrm{MgF}_{2}$, у якому вони утворені. Діаграми взаємозалежностей між параметрами шарів інтерференційної структури та геометричним розміром дефектів, утворених з $\mathrm{ZrO}_{2}$, подано в табл. 3 та на рис. 6, $a$. Залежності від просторового розташування дефекту при його незмінному поздовжньому розмірі $X_{3} A=20$ нм наведено у табл. 4 та на рис. $6, \sigma$. 
ВПЛИВ НАНОДЕФЕКТІВ ШАРІВ НА ПРОПУСКАННЯ СВІТЛА

T а б л ц я 3. Взаємозалежність БШС-D шарів $\mathrm{Y}_{2} \mathrm{~B}$ та $\mathrm{Y}_{3} \mathrm{~B}$ при різних поздовжніх розмірах $\mathrm{X}_{3} \mathrm{~A}$ дефектів $3 \mathrm{ZrO}_{2}$

\begin{tabular}{|c|c|c|c|c|c|c|c|c|c|}
\hline \multirow{2}{*}{$\begin{array}{c}\text { Речовина і позна- } \\
\text { чення шарів }\end{array}$} & \multicolumn{9}{|c|}{ Типи БШC-D і товщини шарів, нм } \\
\hline & БСШ-D0 & БСШ-D1 & БСШ-D2 & БСШ-D3 & БСШ-D4 & БСШ-D5 & БСШ-D6 & БСШ-D7 & БСШ-D8 \\
\hline $\mathrm{ZrO}_{2} \mathrm{X}_{1} \mathrm{~A}$ & 60 & 60 & 60 & 60 & 60 & 60 & 60 & 60 & 60 \\
\hline $\mathrm{MgF}_{2} \mathrm{Y}_{1} \mathrm{~B}$ & 10 & 10 & 10 & 10 & 10 & 10 & 10 & 10 & 10 \\
\hline $\mathrm{ZrO}_{2} \mathrm{X}_{2} \mathrm{~A}$ & 50 & 50 & 50 & 50 & 50 & 50 & 50 & 50 & 50 \\
\hline $\mathrm{MgF}_{2} \mathrm{Y}_{2} \mathrm{~B}$ & 40 & 35 & 30 & 25 & 20 & 15 & 10 & 5 & 0 \\
\hline $\mathrm{ZrO}_{2} \mathrm{X}_{3} \mathrm{~A}$ & 0 & 10 & 20 & 30 & 40 & 50 & 60 & 70 & 80 \\
\hline $\mathrm{MgF}_{2} \mathrm{Y}_{3} \mathrm{~B}$ & 40 & 35 & 30 & 25 & 20 & 15 & 10 & 5 & 0 \\
\hline
\end{tabular}

Т а б л и ц 4. Взаємозалежність БШС-Р шарів розмірами $\mathrm{Y}_{2}$ В і $\mathrm{Y}_{3}$ В при різному просторовому розташуванні дефектів $3 \mathrm{ZrO}_{2}$, що мають поздовжній геометричний розмір $\mathrm{X}_{3} \mathrm{~A}=20$ нм

\begin{tabular}{|c|c|c|c|c|c|c|c|c|}
\hline \multirow{2}{*}{$\begin{array}{c}\text { Речовина і позна- } \\
\text { чення шарів }\end{array}$} & \multicolumn{8}{|c|}{ Типи БШС-P і товщини шарів, нм } \\
\hline & БСШ-P0 & БСШ-P1 & БСШ-Р2 & БСШ-Р3 & БСШ-Р4 & БСШ-Р5 & БСШ-P6 & БСШ-P7 \\
\hline $\mathrm{ZrO}_{2} \mathrm{X}_{1} \mathrm{~A}$ & 60 & 60 & 60 & 60 & 60 & 60 & 60 & 60 \\
\hline $\mathrm{MgF}_{2} \mathrm{Y}_{1} \mathrm{~B}$ & 10 & 10 & 10 & 10 & 10 & 10 & 10 & 10 \\
\hline $\mathrm{ZrO}_{2} \mathrm{X}_{2} \mathrm{~A}$ & 50 & 50 & 50 & 50 & 50 & 50 & 50 & 50 \\
\hline $\mathrm{MgF}_{2} \mathrm{Y}_{2} \mathrm{~B}$ & 40 & 0 & 10 & 20 & 30 & 40 & 50 & 60 \\
\hline $\mathrm{ZrO}_{2} \mathrm{X}_{3} \mathrm{~A}$ & 0 & 20 & 20 & 20 & 20 & 20 & 20 & 20 \\
\hline $\mathrm{MgF}_{2} \mathrm{Y}_{3} \mathrm{~B}$ & 40 & 60 & 50 & 40 & 30 & 20 & 10 & 0 \\
\hline
\end{tabular}

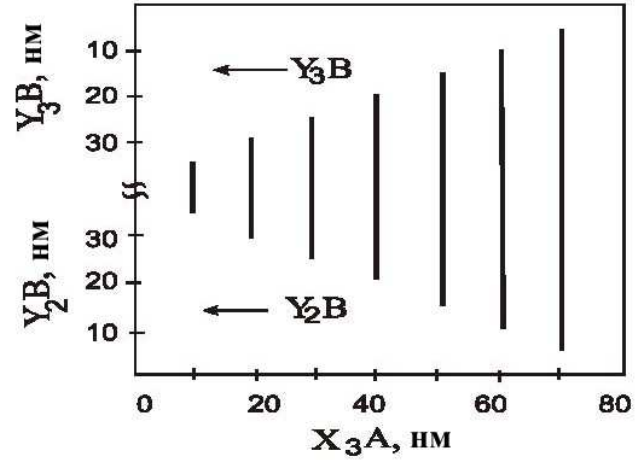

$a$

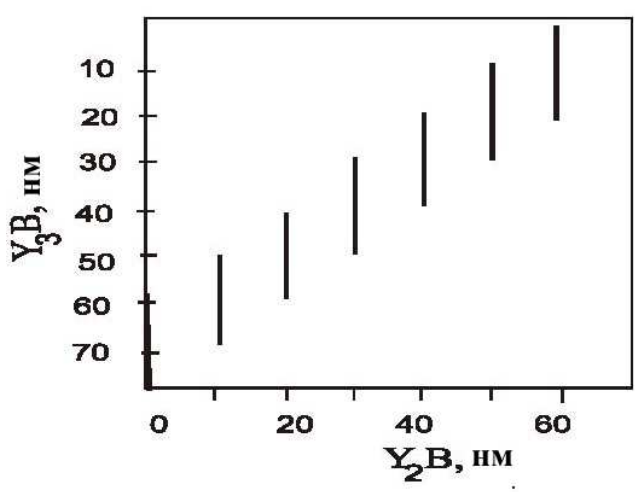

6

Рис. 6. Діаграма взаємозалежностей між параметрами БШС і поздовжнім розміром дефектів $(a)$ та їх просторовим розташуванням (б)
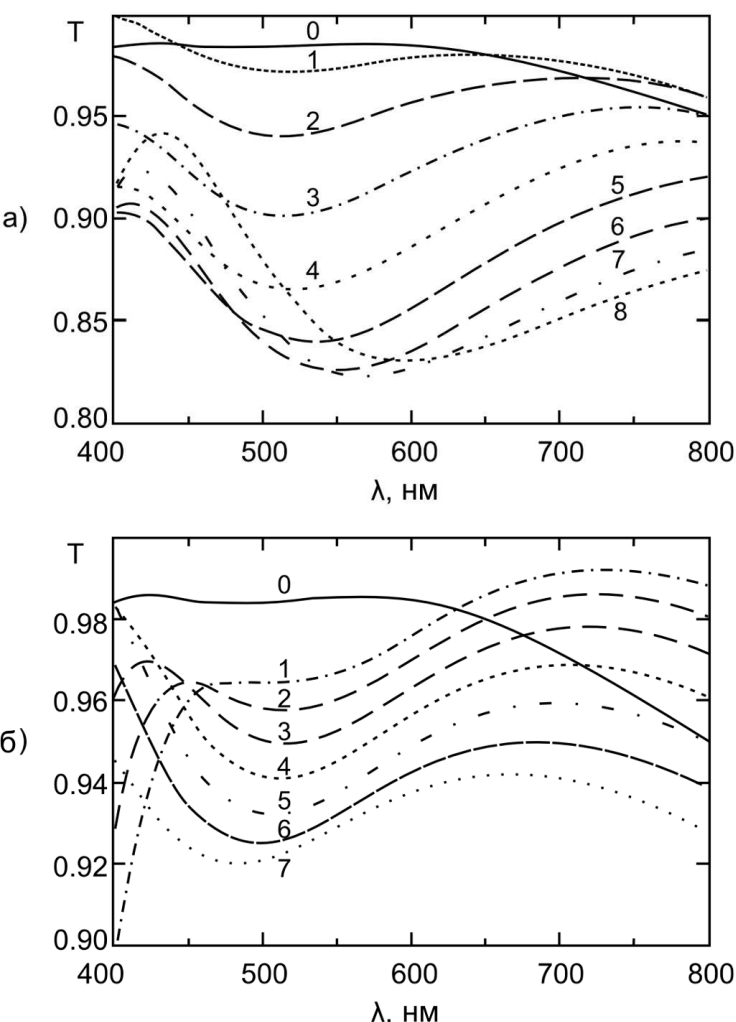

Рис. 7. Залежності спектрів пропускання БШС від поздовжнього розміру дефектів ( $a$, криві $0-7$, дані з табл. 3 , діаграма на рис. $6, a)$ та від їхнього просторового розташування $(6$, криві 0 7, дані з табл. 4, діаграма на рис. 6,б) 
Спектри пропускання, що відповідають діаграмі, зображеній на рис. 6,a, та параметрам шарів 3 табл. 3, показано на рис. 7, $a$. Як бачимо з цього рисунка, при збільшенні поздовжнього розміру дефекту, утвореного речовиною з високим показником заломлення, виникає мінімум пропускання в області 500-550 нм, положення якого зсувається в довгохвильову область спектра. Подібна залежність спостерігається також при зміні положення дефекту відносно центральної точки (табл. 4 і діаграма на рис. 6,б). Однак, як видно з рис. 7,6, при наближенні дефекта до границі середовищ утворюваний мінімум зсувається в короткохвильову область спектра.

\section{4. Висновки}

Враховано можливість існування нанодефектів у просвітлюючих шарах інтерференційних покриттів, які приводять до відхилення оптичних параметрів реальних структур від необхідних за вимогами технології.

Для числових оцінок впливу параметрів дефектів на рівень пропускання БШС запропоновано модель структури дефектного шару, за якою було встановлено взаємозв'язок між геометричними та оптичними товщинами суміжних шарів залежно від параметрів дефектів: їхньої природи, розмірів і положень відносно меж поділу дефектного шару та суміжних середовищ.

Встановлено, що максимуми пропускання оптичних елементів з реальними дефектними покриттями знижуються зі зростанням показників заломлення речовин дефектів, а їх спектральне положення та форма кривих істотно залежать від розмірів дефектів уздовж напрямку поширення світла та їх положення в об'ємі дефектного шару.

Отримані результати мають важливе значення для виготовлення оптичних елементів (особливо лінз для окулярів) з просвітлюючими покриттями.

1. M. Popesku, A. Andriesh, V. Ciumas et.al., Optoel. and Adv. Mat. 7, 4 (2005).

2. M. D. Fontana et. al., Proc. 11-th Europhys. Conf. on Defects in insulating materials, (Pech, Hungary, 2010).

3. Д.М. Фреїк та ін. Тези доповідей I міжнародной конференції "Напівпровідникові матеріали, інформачійні технологї та фотовольтаӥка" (Кременчук, 2011).

4. I.V. Fekeshgazi et. al., Proc. Intern. Scient. Conf. "Physical and. chemical principles of formation and modificanion of micro- and nanostructures" (Kharkov, October 2009).
5. П.П. Яковлев, Б.Б. Мешков, Проектирование интерференционных покрытий (Машиностроение, Москва, 1987).

6. М. Борн, Э. Вольф, Основы оптики (Наука, Москва, 1970).

7. F. Abeles, Ann. de Physique 5, 596 (1950).

8. Y. Pervak, A. Mitsa, J. Holovach, I. Fekeshgazi, Proc. SPIE 4425, 321 (2000).

9. П. Барна, О.Є. Кікінеші, О.В. Міца, Т.С. Сіденко, I.В. Фекешгазі, Мат. електр. техн. та сучасні інформаційні технологї (Кременчук, травень 2010).

10. P. Barna, O.E. Kikineshi, O.V. Mitsa, T.S. Sidenko, I.V. Fekeshgazi Book of abstr. 11-th Europhys Conf. on Defect in Insulating Mater (Hungary, Pech, July 2010).

Одержано 20.01.11

\section{ВЛИЯНИЕ НАНОДЕФЕКТОВ СЛОЕВ НА ПРОПУСКАНИЕ СВЕТА ОПТИЧЕСКИМИ ЭЛЕМЕНТАМИ С МНОГОСЛОЙНЫМИ ИНТЕРФЕРЕНЦИОННЫМИ ПОКРЫТИЯМИ}

И.В. Фекешгази, Т.С. Сиденко, А.В. Мица, П. Барна,

A.Е. Кикинеши

$\mathrm{P}$ е $з$ ю м е

Исследована зависимость пропускания света оптическими элементами с многослойными интерференционными покрытиями. Установлено, что максимумы пропускания оптических элементов с реальными покрытиями, содержащими дефекты, понижаются тем сильнее, чем выше показатели преломления вещества дефектов, а форма кривых пропускания существенно зависит от размеров дефектов вдоль направления распространения света и их положения в объеме дефектного слоя. Данные результаты необходимы для отработки технологии изготовления оптических элементов с многослойными интерференционными покрытиями как для лазерной техники, так и для производства оптических линз.

\section{EFFECTS OF LAYER NANODEFECTS ON THE LIGHT TRANSMISSION BY OPTICAL ELEMENTS WITH MULTILAYER INTERFERENCE COATINGS}

I.V. Fekeshgazi ${ }^{1}$, T.S. Sidenko ${ }^{1}$, O.V. Mitsa ${ }^{2}$, P. Barna ${ }^{3}$, O.E. Kikineshi ${ }^{4}$

${ }^{1}$ Institute of Semiconductor Physics, Nat. Acad. Sci. of Ukraine (41, Nauky Ave., Kyiv 03028, Ukraine; e-mail: fek_i@yahoo.com), ${ }^{2}$ Uzhhorod State University

(54, Voloshyn Str., Uzhhorod 88000, Ukraine;

e-mail: alex_mitsa@mail.ru),

${ }^{3}$ Research Institute of Technical Physics and Materials Science,

Hungarian Academy of Sciences

(29-33, Konkoly-Thege út., Budapest 1121, Hungary;

e-mail:barnap@mfa.kfki.hu), 
${ }^{4}$ Institute for Nuclear Research, Hungarian Academy of Sciences (Middelheimlaan, 1, Deberzen 2020, Hungary)

$\mathrm{S} u \mathrm{~m} m$ a r y

The light transmission properties of optical elements with multilayer interference coatings have been studied. The reduction of transmittance maxima for optical elements with coating containing defects is found to be stronger for larger re- fractive indices of the substances that the defects are made of. The shape of transmittance curves is found to substantially depend on the defect dimensions along the direction of light propagation and the defect arrangement in the layer bulk. The results obtained are necessary for the developing of a technology aimed at manufacturing the optical elements with multilayer interference coatings for laser facilities and optical lenses. 